\title{
Profil Pasien Suspek Resistensi Ganda Tuberkulosis HIV/AIDS di Rumah Sakit Penyakit Infeksi (RSPI) Prof. Dr. Sulianti Saroso Tahun 2012
}

\author{
Profile of Suspected Multiple Drug Resistance Tuberculosis HIV/AIDS Patients in \\ Infectious Disease Hospital Prof. Dr. Sulianti Saroso 2012
}

\author{
Pompini Agustina*, Huda Rahmawati, Adria Rusli, Titi Sundari, Ida Bagus Sila \\ Wiweka
}

Rumah Sakit Penyakit Infeksi (RSPI) Prof. Dr. Sulianti Saroso

*Korespondensi Penulis :

dr.Pompini Agustina, SpP

Email : pompiniagustina@yahoo.com

\begin{abstract}
Abstrak
Latar belakang : Tuberkulosis (TB) adalah penyakit infeksi yang disebabkan Mycobacterium tuberculosis terutama menyerang paru. Laporan World Health Organization (WHO) menuliskan pada umumnya hanya sedikit orang yang terinfeksi TB menjadi sakit TB namun pada orang dengan HIV/AIDS yang terinfeksi TB banyak menjadi sakit TB. Resistensi terhadap Obat Anti Tuberkulosa (OAT) menjadi salah satu masalah penting dalam pengobatan TB. Ketersediaan obat yang ampuh tetapi tidak diberikan dengan baik menimbulkan masalah resistensi termasuk Resistensi Ganda (RG)/ Multidrug Resistant (MDR).

Metode : Penelitian ini mempunyai desain deskriptif potong lintang menggunakan data yang sudah direkapitulasi dari case report form (CRF). Sampel penelitian ini adalah pasien suspek resistensi ganda TB pada HIV. Kriteria inklusi adalah semua pasien usia $\geq 15$ tahun dengan HIV TB Paru BTA positif atau negatif kasus baru, kasus kambuh, kasus putus obat, gagal terapi (suspek resistensi ganda) yang berobat ke Instalasi rawat jalan maupun Instalasi rawat inap RSPI Prof Dr. Sulianti Saroso. Sampel berjumlah 21 orang pasien suspek resistensi ganda TB HIV/AIDS periode Maret - Desember 2012 di RSPI Prof dr Sulianti Saroso. Hasil disajikan ke dalam bentuk tabel distribusi frekuensi kemudian dianalisis secara univariat.

Hasil : Secara keseluruhan kelompok pasien suspek resistensi ganda TB HIV/AIDS paling banyak didapatkan pada usia 15-35 tahun sebesar 18 orang (85,7\%), sebanyak 7 orang $(33,33 \%)$ bekerja dengan pekerjaan sebagai karyawan, tingkat pendidikan paling banyak Sekolah Menengah Atas berjumlah 15 orang $(71,4 \%)$ dan faktor risiko pasien paling banyak dari seks bebas dengan jumlah 13 orang $(61,9 \%)$, Hasil pemeriksaan laboratorium menunjukkan jumlah CD4 pasien cenderung rendah yaitu CD4 <100 sel/ $\mu \mathrm{L}$ berjumlah 18 orang $(66,7 \%)$, sementara jumlah limfosit paling banyak antara $15 \%$ sampai $40 \%$ sebanyak 10 orang $(47,6 \%)$.

Kesimpulan : Profil pasien suspek resistensi ganda TB HIV/AIDS RSPI Prof dr Sulianti Saroso pada kelompok usia produktif dengan faktor risiko utama adalah seks bebas dan kondisi sistem kekebalan tubuh buruk.
\end{abstract}

Kata kunci : Resistensi ganda TB, HIV/AIDS, Profil

\begin{abstract}
Background : Tuberculosis (TB) is an infectious disease caused by Mycobacterium tuberculosis mainly affects the lungs. WHO Reports wrote in general only a few people who are infected with TB become ill TB but people with HIV-infected TB are becoming sick with TB. Resistance to OAT become one of the important problems in the treatment of tuberculosis. Availability panacea but is not provided with either raises the problem of resistance including dual resistance (RG) / MDR (multidrug resistant).

Methods : This study had descriptive cross-sectional design using the data that had been summarized from the case report form (CRF). Samples was taken of patients with suspected TB dual resistance to HIV. Inclusion criteria was all patients aged > 15 years with HIV-TB BTA positive or negative new cases, relapse cases, cases of drug withdrawal, failed therapy (suspected double resistance) who went to the
\end{abstract}


Installation outpatient or inpatient Installation RSPI Prof Dr. Sulianti Saroso. Sample of 21 patients with suspected TB dual resistance to HIV / AIDS the period from March to December 2012 in RSPI Prof. Dr. Sulianti Saroso. Results are presented in a frequency distribution table and then analyzed by univariate.

Results : Overall duplex suspected resistance of TB \& HIVIAIDS patients group, most widely was obtained at age 15-35 years amount to 18 people (85.7\%) consist of 7 people (33.33\%) working as employee, highest number of education level was high school amount to 15 people (71.4\%), Number of CD4 patients tended to be lower which was CD4 $<100$ cells $/ \mathrm{mL}$ amount to 18 people (66.7\%), the highest number of lymphocytes was between $15 \%$ and $40 \%$ amount to 10 people $(47,6 \%)$ and the highest risk factor of patients was from free sex amount to 13 people (61.9\%).

Conclusion : Dual resistance profile of patients with suspected TB HIV / AIDS RSPI Prof. Dr. Sulianti Saroso the productive age group with the main risk factor is sex and condition of the immune system worse.

Keywords : MDR TB, HIV/AIDS, Profile

\section{Pendahuluan}

Tuberkulosis (TB) masih menjadi perhatian utama masalah kesehatan dunia meskipun efikasi pengobatan cukup tinggi dan merupakan penyebab kematian tertinggi di dunia karena penyakit infeksi. Keterlambatan dalam penegakkan diagnosis TB paru mungkin menjadi penyumbang penting tingginya angka kematian. Laporan WHO 2010 menyebutkan diperkirakan terdapat $440.000 \quad(390.000-510.000)$ kasus resistensi ganda yang didefinisikan sebagai kuman TB yang resisten sekurangnya terhadap rifampisin (R) dan isoniazid (INH). Sedangkan pada tahun 2010 WHO memperkirakan terdapat 650.000 kasus MDR TB dari semua kasus TB. Hal ini menjadikannya sebagai kasus kegawatan global pada tahun 2006. ${ }^{1}$

$$
\text { Epidemi }
$$

Human

Immunodeficiency Virus (HIV) dan Acquired Immune Deficiency Syndrome (AIDS) merupakan permasalahan kesehatan masyarakat global yang terus mengancam. WHO memperkirakan secara kumulatif sampai tahun 2013 orang yang terinfeksi HIV mencapai 35 juta orang. Jumlah tertinggi tercatat di regional Sub Sahara sekitar 24.7 juta dan regional Asia Pasifik sekitar 4.8 juta. $^{2}$ Saat ini epidemi HIV di Indonesia termasuk yang tercepat di Asia. $^{3}$ Jumlah kumulatif infeksi HIV yang tercatat di Indonesia sampai dengan September 2014 sebanyak 150.296 kasus dengan tren dari tahun ke tahun terus menunjukkan peningkatan yaitu 21.031 kasus pada tahun 2011, 21.511 pada tahun 2012 dan 29.037 pada tahun 2013. Namun demikian case fatality rate (CFR) akibat HIV/AIDS di Indonesia dilaporkan $3.58 \%$ pada tahun 2011, 3.79\% pada tahun 2012 dan hanya 1,67\% pada tahun 2013 . Jumlah kumulatif infeksi HIV tertinggi di Indonesia adalah di Provinsi Daerah Khusus Ibukota (DKI) Jakarta yang telah mencapai 32.782 kasus. $^{4}$ 
Perilaku berisiko tinggi untuk penularan HIV terutama adalah seks bebas dan berganti-ganti pasangan, baik heteroseksual maupun homoseksual, pengguna narkoba suntik atau injecting drug user (IDU). ${ }^{5}$ Penularan HIV dari ibu dengan status HIV positif kepada bayi/anak juga dapat terjadi baik selama kehamilan, persalinan dan masa menyusui. Penularan HIV juga bisa terjadi pada penggunaan alat tindik atau tatto yang tidak steril bekas digunakan ODHA atau tranfusi darah oleh donor dengan HIV positif. ${ }^{6}$

Angka kejadian TB-HIV yang terus meningkat menyebabkan banyak praktisi kesehatan maupun pemerintah menaruh perhatian yang cukup serius. HIV menjadikan tuberkulosis menjadi suatu penyakit yang epidemis di seluruh dunia, sedangkan tuberkulosis adalah infeksi oppurtunistik yang menyebabkan angka kematian paling tinggi pada penderita HIV/AIDS. ${ }^{7,8}$

Sejumlah pasien di RSPI Prof. Dr. Sulianti Saroso adalah suspek resistensi ganda TB HIV/AIDS. Banyak faktor dari pasien yang mungkin berhubungan dengan tingginya angka kejadian resistensi ganda TB HIV/AIDS ini dan memunculkan karakteristik tertentu. Maka diperlukan adanya profil pasien suspek resistensi ganda TB HIV/AIDS.

\section{Metode}

Rancangan penelitian ini adalah deskriptif potong lintang. Pengambilan data primer menggunakan Case Report Form (CFR) dilakukan pada bulan Maret - Desember 2012. Sampel penelitian ini adalah pasien suspek resistensi ganda TB pada HIV. Kriteria inklusi adalah semua pasien usia $\geq 15$ tahun dengan HIV TB Paru BTA positif atau negatif kasus baru, kasus kambuh, kasus putus obat, gagal terapi (suspek resistensi ganda) yang berobat ke rawat jalan maupun rawat inap RSPI Prof Dr. Sulianti Saroso dan sukarela mengikuti penelitian dengan menandatangani lembar persetujuan setelah mendapatkan informasi lembar penjelasan.

Hasil disajikan ke dalam bentuk tabel distribusi frekuensi kemudian dianalisis secara univariat untuk menjelaskan gambaran profil pasien suspek resisten ganda TB HIV/AIDS RSPI Prof dr Sulianti Saroso bulan Maret-Desember tahun 2012. Penelitian ini telah mendapatkan ethical clearance dari Komisi Etik Fakultas Kedokteran Universitas Indonesia - Rumah Sakit Cipto Mangunkusumo.

\section{Hasil}

Jumlah sampel awal sebanyak 35 pasien, namun pasien dengan data lengkap sejumlah 21 sampel, sehingga 
14 pasien dikeluarkan dari sampel penelitian. Karakteristik pasien lebih banyak ditemukan pada usia 15-35 tahun sejumlah 18 orang $(85,7 \%)$ dibandingkan pada usia > 35 tahun yaitu 3 orang (14,3\%). Pasien suspek resistensi ganda TB HIV/AIDS lebih banyak ditemukan pada golongan bekerja dengan pekerjaan sebagai karyawan sebesar 7 orang (33,33\%), wiraswasta 2 orang $(9,5 \%)$, Ibu Rumah Tangga (IRT) 2 orang (9,5\%), lain-lain 2 orang $(9,5 \%)$, supir pribadi 1 orang $(4,8 \%)$, seniman 1 orang $(4,8 \%)$, buruh 1 orang $(4,8 \%)$ dan tidak bekerja 5 orang $(23,8 \%)$ Tingkat pendidikan pasien suspek resistensi ganda TB HIV/AIDS cenderung lebih banyak di sekolah menengah atas dengan jumlah 15 orang $(71,4 \%)$ dan tidak ada yang SD. Hasil dapat dilihat pada table 1.

Faktor risiko pasien suspek resistensi ganda TB HIV/AIDS paling banyak dari seks bebas dengan jumlah 13 orang $(61,9 \%)$, drugs abuser suntik sebanyak 6 orang $(28,6 \%)$, seks bebas \& drugs abuser suntik sebanyak 6 orang $(28,6 \%)$, heteroseksual sebanyak 6 orang $(28,6 \%)$, homoseksual 1 orang (4,8\%), pasangan HIV sebanyak 4 orang (19,0\%) (Tabel 2).
Tabel 1. Distribusi Proporsi Pasien suspek resistensi ganda TB HIV/AIDS Berdasarkan data demografi

\begin{tabular}{lcc}
\hline Data Demografi & Jumlah & Presentase \\
\hline Usia (Tahun ) & & \\
- $15-35$ & 18 & 85.7 \\
- > 35 & 3 & 14.3 \\
Pekerjaan & & \\
- Karyawan & 7 & 33.3 \\
- Tidak bekerja & 5 & 23.8 \\
- Wiraswasta & 2 & 9.5 \\
- IRT & 2 & 9.5 \\
- lain-lain & 2 & 9.5 \\
- Supir Pribadi & 1 & 4.8 \\
- Seniman & 1 & 4.8 \\
- buruh & 1 & 4.8 \\
Pendidikan & & \\
- SMP & 3 & 14.3 \\
- SMA/STM/SMK & 15 & 71.4 \\
- D3 & 1 & 4.8 \\
- S1 & 2 & 9.5 \\
\hline
\end{tabular}

Tabel 2. Distribusi Proporsi Pasien suspek resistensi ganda TB HIV/AIDS Berdasarkan Faktor Risiko

\begin{tabular}{lcc}
\hline Faktor Risiko & Jumlah & Presentase \\
\hline Sex Bebas & 13 & 61,9 \\
Homoseksual & 1 & 4,8 \\
Heteroseksual & 6 & 28,6 \\
$\begin{array}{l}\text { Drugs abuser } \\
\text { suntik }\end{array}$ & 6 & 28,6 \\
$\begin{array}{l}\text { Seks Bebas \& } \\
\text { Drugs abuser }\end{array}$ & 6 & 28,6 \\
$\begin{array}{l}\text { suntik } \\
\text { Pasangan HIV }\end{array}$ & 4 & 19,0 \\
\hline Jumlah & 21 & 100,0 \\
\hline
\end{tabular}

Jumlah CD4 Pasien suspek resistensi ganda TB HIV/AIDS cenderung rendah dengan 18 orang $(66,7 \%)$ yang memiliki CD4 $<100$ sel $/ \mu \mathrm{L}$ dan 7 pasien (33,3\%) yang memiliki CD4 100-200 sel/ $\mu \mathrm{L}$. Rerata jumlah CD4 pada pasien adalah 58 sel/ $\mu \mathrm{L}$ (Tabel 3). 
Tabel 3. Distribusi Proporsi Pasien suspek resistensi ganda TB HIV/AIDS Berdasarkan Jumlah CD4

\begin{tabular}{lcc}
\hline $\begin{array}{l}\text { Jumlah CD4 } \\
(\mathrm{sel} / \mu \mathrm{L})\end{array}$ & Jumlah & Presentase \\
\hline$<100$ & 14 & 66,7 \\
$100-200$ & 7 & 33,3 \\
\hline Jumlah & 21 & 100,0 \\
\hline
\end{tabular}

Jumlah limfosit pasien suspek resistensi ganda TB HIV/AIDS yang < $15 \%$ sebanyak 8 orang $(38,1 \%)$, antara $15 \%$ sampai $40 \%$ sebanyak 10 orang $(47,6)$ dan $>40 \%$ sebanyak 3 orang (14,3\%) (tabel 4).

Tabel 4. Distribusi Proporsi Pasien suspek resistensi ganda TB HIV/AIDS Berdasarkan Jumlah Limfosit

\begin{tabular}{lcc}
\hline Jumlah limfosit & Jumlah & Presentase \\
\hline$<15$ & 8 & 38,1 \\
$15-40$ & 10 & 47,6 \\
$>40$ & 3 & 14,3 \\
\hline Jumlah & 21 & 100,0 \\
\hline
\end{tabular}

\section{Pembahasan}

Pada penelitian ini menggunakan sampel sebanyak 21 orang pasien suspek resistensi ganda TB HIV/AIDS. Pada kategori umur didapatkan pasien dengan umur 15-35 tahun memiliki presentase terbanyak dengan jumlah $15-35$ tahun sebesar 18 orang $(85,7 \%)$ dan pada usia $>35$ tahun yaitu 3 orang (14,3\%). Hal ini sesuai dengan penelitian Dwi Alfian Heru yang juga menyebutkan bahwa kelompok umur
15-35 tahun memiliki angka kejadian TB HIV/AIDS tertinggi. ${ }^{9}$

Pasien yang bekerja memiliki presentase terbanyak dengan pekerjaan sebagai karyawan sebesar 7 orang (33,33\%), jenis pekerjaan lainnya yaitu wiraswasta, IRT, buruh, seniman, supir pribadi dan lain-lain serta tidak bekerja 5 orang ( 23,8\%). Hal ini sesuai dengan pernyataan The National AIDS Fund bahwa penderita HIV memiliki risiko pajanan terhadap TB yang lebih besar di tempat bekerja. $^{10}$

Tingkat pendidikan pasien suspek resistensi ganda TB HIV/AIDS paling banyak pada tingkat pendidikan menengah atas baik umum ataupun kejuruan sebanyak 15 orang (71,4\%). Pendidikan dapat meningkatkan kematangan intelektual seseorang. Kemampuan intelektual ini berpengaruh pada wawasan, cara berfikir, baik dalam cara pengambilan keputusan maupun dalam pembuatan kebijakan. ${ }^{11}$

Jumlah CD4 pasien suspek resistensi ganda TB HIV/AIDS cenderung rendah dengan yang memiliki CD4 <100 sel/ $\mu \mathrm{L}$ berjumlah 18 orang $(66,7 \%)$ dan rerata $58 \mathrm{sel} / \mu$. Hal ini sesuai dengan penelitian Dwi Alfian Heru yang juga menyebutkan bahwa pasien TB HIV/AIDS cenderung memiliki CD4 <100 sel/ $\mu \mathrm{L} .{ }^{12}$ Selain itu 
penelitian di Zimbabwe dimana diperoleh hasil $72 \%$ jumlah CD4 pasien TB-HIV dibawah $200 \mathrm{sel} / \mu \mathrm{L}^{13}$ Keberadaan TB pada pasien HIV/AIDS akan mempercepat penurunan imunitas. $^{14}$

Jumlah persen limfosit yang $<15$ $\%$ sebanyak 8 orang $(38,1 \%)$, antara $15 \%$ sampai $40 \%$ sebanyak 10 orang $(47,6 \%)$ dan $>40 \%$ sebanyak 3 orang $(14,3 \%)$. Faktor risiko pasien suspek resistensi ganda TB HIV/AIDS paling banyak dari seks bebas dengan jumlah 13 orang $(61,9 \%)$, drugs abuser suntik sebanyak 6 orang (28,6\%), seks bebas \& drugs abuser suntik sebanyak 6 orang (28,6\%), heteroseksual sebanyak 6 orang $(28,6 \%)$, homoseksual 1 orang $(4,8 \%)$, pasangan HIV sebanyak 4 orang $(19,0 \%)$ dan orang tua HIV tidak ada. Hal ini sesuai dengan penelitian Aesthetica Islamy bahwa risiko kejadian ko-infeksi TB HIV/AIDS lebih besar pada responden dengan paparan faktor risiko hubungan seks dengan pasangan berisiko tinggi dan hubungan seks tidak aman (anal seks). ${ }^{15}$

\section{Kesimpulan}

Pasien suspek resistensi ganda TB HIV/AIDS pada periode Maret Desember 2012 di RSPI Prof. Dr. Sulianti Saroso sebagian besar berada pada kelompok usia produktif dengan faktor risiko utama seks bebas serta kondisi kekebalan tubuh dalam keadaan buruk secara analisa hasil laboratorium.

\section{Ucapan Terima Kasih}

Penulis ucapkan terima kasih kepada institusi RSPI Prof. Dr. Sulianti Saroso dan semua pihak yang terlibat atas kontribusi dan bantuan dalam proses pengumpulan serta analisi data.

\section{Daftar Pustaka}

1. WHO. Global tuberculosis control: WHO report 2011. Who [Internet]. 2011;258. Available from:

http://www.who.int/tb/publications /global_report/en/index.html

2. UNAIDS. Global Report: UNAIDS report on the global AIDS epidemic 2014. Genebra. 2014;(July).

3. Kemenkes RI. Lembar fakta situasi terkini kemajuan pengendalian tuberkulosis 2014 . jakarta; 2014.

4. Kemenkes RI. laporan situasi perkembangan HIV/AIDS di indonesia tahun 2014. jakarta; 2014.

5. Azmi AS. Prevalensi Risiko Tuberkulosis Multi Drug Resistance ( TB-MDR ) di Kota Depok : 2013.

6. Kemenkes RI. Pedoman Nasional Tatalaksana klinis infeksi HIV dan terapi antiretroviral pada orang dewasa. 
jakarta; 2011.

7. Straetemans $M$. The effect of tuberculosis on mortality in HIV positive people: a meta analysis. PLoS One. 2010.

8. A U. TB/HIV COINFECTION. FKUI/RSCM; 2009.

9. A Dwi. Profil Pasien Koinfeksi TB-HIV di Rumah Sakit Umum Pusat Sanglah Bali. e-jurnal Med. 2016;5.

10. Gunaseelan A. Karakteristik Pasien HIV dengan Tuberkulosis di RSUP Haji Adam Malik Medan tahun 2008-2010. 2010.

11. Suarni N. Faktor risiko yang berhubungan dengan kejadian penderita penyakit TB Paru BTA Positif di kecamatan pancoran mas kota depok. Depok: FKM UI; 2009.

12. Permitasari DA. Faktor Resiko Terjadinya Tuberkulosis pada Pasien HIV/AIDS di RSUP DR. KARIADI Semarang. 2012;1-54. Available from: http://webcache.googleusercont ent.com/search?q=cache:jCfP1 $h$ ND7kAJ:core.ac.uk/download/pd $\mathrm{f} / 11735781 . \mathrm{pdf}+\& \mathrm{~cd}=5 \& \mathrm{hl}=\mathrm{id} \& \mathrm{ct}$ $=$ clnk\&gl=id.

13. Nzou C K R. clinical predictor of low CD4 count among HIV
Infected Pulmonary. 2010.

14. Hoffman. HIV Medicine 2007 [Internet]. 2007. Available from: www.hivmedicine.com

15. Islamy A. Analisis faktor risiko ko-infeksi tb-hiv pada pasien tb di bp4/rs karang tembok surabaya aesthetica islamy. 2010;4-5. 